\title{
Quantification of Staphylococcus aureus in white cheese by the improved DNA extraction strategy combined with TaqMan and LNA probe-based qPCR
}

\author{
Pınar Kadiroğlu ${ }^{1}$, Figen Korel ${ }^{*}$, Cagatay Ceylan ** \\ Department of Food Engineering, İzmir Institute of Technology, Urla, Izmir, Turkey
}

\section{A R T I C L E I N F O}

\section{Article history:}

Received 12 May 2014

Received in revised form 30 June 2014

Accepted 30 June 2014

Available online 10 July 2014

\section{Keywords:}

Cheese

Staphylococcus aureus

qPCR

TaqMan

LNA

\begin{abstract}
A B S T R A C T
Four different bacterial DNA extraction strategies and two different qPCR probe chemistries were studied for detection of Stapylococcus aureus from white cheeses. Method employing trypsin treatment followed by a commercial kit application and TaqMan probe-based qPCR was the most sensitive one detecting higher counts than standards in naturally contaminated samples.
\end{abstract}

(c) 2014 Elsevier B.V. All rights reserved.

\section{Introduction}

Staphylococcus aureus infections and intoxications related to consumption of contaminated cheese have significance for product quality and public health (Temelli et al., 2006, Morandi et al., 2007). The European Food Safety Authority (EFSA) reported that cheeses with mixed and buffet meals were the two main ways involved in food poisoning outbreaks caused by staphylococcal toxins (Schelin et al., 2011). In addition, in Turkey, the most widely consumed cheese type is Turkish white cheese with an approximate production rate of $67 \%$ (Temelli et al., 2006). There have been several reports of S. aureus contamination in cheeses and other foods (Hein et al., 2005; Peles et al., 2007; Huong et al., 2010; Ertas et al., 2010; Alaboudi et al., 2012; Hummerjohann et al., 2014).

Cheese can be an important source of $S$. aureus contamination through raw milk, inadequate pasteurization process and improper conditions after pasteurization or production area (Miranda et al., 2009). For evaluating the safety of food production process, it is important to quantify the changes in microbial numbers (Schelin et al., 2011). Traditional microbiological methods have several drawbacks such as

\footnotetext{
* Corresponding author. Tel.: +90 232 7506228; fax: +90 2327506196.

** Corresponding author. Tel.: + 90232 7506328; fax: +90 2327506196 .

E-mail addresses: pkadiroglu@adanabtu.edu.tr (P. Kadiroğlu), figenkorel@iyte.edu.tr (F. Korel), cagatayceylan@iyte.edu.tr (C. Ceylan).

1 Present address: Adana Science and Technology University, Department of Food Engineering, Seyhan, Adana, Turkey. Tel.: +90 322 4552120; fax: +90 3224550009.
}

long detection time, high cost, and low sensitivity (Cremonesi et al., 2007). Quantitative PCR (qPCR) is increasingly used as a rapid, specific, and sensitive method for reliable detection and accurate gene quantification (Ginzinger, 2002). The advantages of qPCR are high sensitivity, high specificity, and lower risks of cross-contamination (Abdunaser et al., 2009). Several studies have been performed by qPCR to detect and quantify different bacterial cells in food products (D'Urso et al., 2009; Martínez-Blanch et al., 2009; Pennacchia et al., 2009). Several studies have been carried out on detection of $S$. aureus in food samples by qPCR method (Alarcón et al., 2006; Fusco et al., 2011; Hein et al., 2001; Poli et al., 2007). Cheese is a difficult matrix for direct S. aureus detection and quantification by qPCR method due to its high fat content (Ercolini et al., 2004). There have been few studies on the development of DNA extraction methods directly from food samples for detection of S. aureus. In one of these studies 33 bovine and caprine raw milk cheese samples were investigated and DNA extraction method was developed with a detection level of $100 \mathrm{CFU} / \mathrm{g}$ for S. aureus (Cremonesi et al. 2007).

Different PCR technologies have been developed for better detection purposes mainly based on novel primer and probe chemistries. Two important chemistries that are used in qPCR systems are TaqMan and LNA probes that specifically bind to the target sequence (Gachon et al., 2004). Locked nucleic acid (LNA) is the analogue of a nucleic acid described by the Wengel and Imanishi laboratories (Letertre et al., 2003). The C $3^{\prime}$-endo type sugars are conformationally locked by a methylene bridge between $2^{\prime}$ oxygen and $4^{\prime}$ carbon of the ribose ring (Jepsen 
et al., 2004). The flexibility of the ribofuranose ring is reduced by this methylene bridge causing the formation of a rigid bicyclic monomer. This also increases the local organization of the phosphate backbone and result in strong hybridization between two DNA strands (Letertre et al., 2003; Reynisson et al., 2006). To the best of our knowledge, the studies on direct quantitative detection of $S$. aureus in Turkish cheese samples are very limited. In addition, optimization of a method for one food system may not be applicable to other food samples (Federico et al., 2005). The purpose of this study is to improve the detection sensitivity of $S$. aureus by experiencing different bacterial DNA extraction methods directly isolated from cheese samples. In addition, the comparison of TaqMan and LNA probes in the qPCR assays for the sensitive detection and quantification of $S$. aureus bacterial cells by targeting species specific nuc gene was proposed in artificially and naturally contaminated Turkish white cheese samples.

\section{Materials and method}

\subsection{Bacterial strain and DNA isolation}

S. aureus RSKK 1009 strain was used to prepare quantification standard and for artificial inoculation of cheese samples. The reference strain was grown in $6 \mathrm{~mL}$ of Tryptic soy broth (Merck, Darmstadt, Germany) and incubated at $37{ }^{\circ} \mathrm{C}$ for $18 \mathrm{~h}$. The turbidity of bacterial suspension in Tryptic soy broth was adjusted to $0.5 \mathrm{McF}$ arland $\left(10^{7} \mathrm{CFU} / \mathrm{mL}\right)$. Tenfold serial dilutions were prepared from this suspension. Colonies were enumerated by plating onto Baird Parker Agar (BD-Difco ${ }^{\mathrm{TM}}$, France) supplemented with egg yolk tellurite emulsion (BBL®, USA). DNA extraction from the pure culture was performed according to the method described previously (Sudagidan et al., 2008).

\subsection{Artificially and naturally contaminated white cheese samples}

The detection ranges of TaqMan and LNA probes in artificially contaminated cheese samples were determined by inoculating tenfold serial dilutions of pure culture to white cheese samples purchased

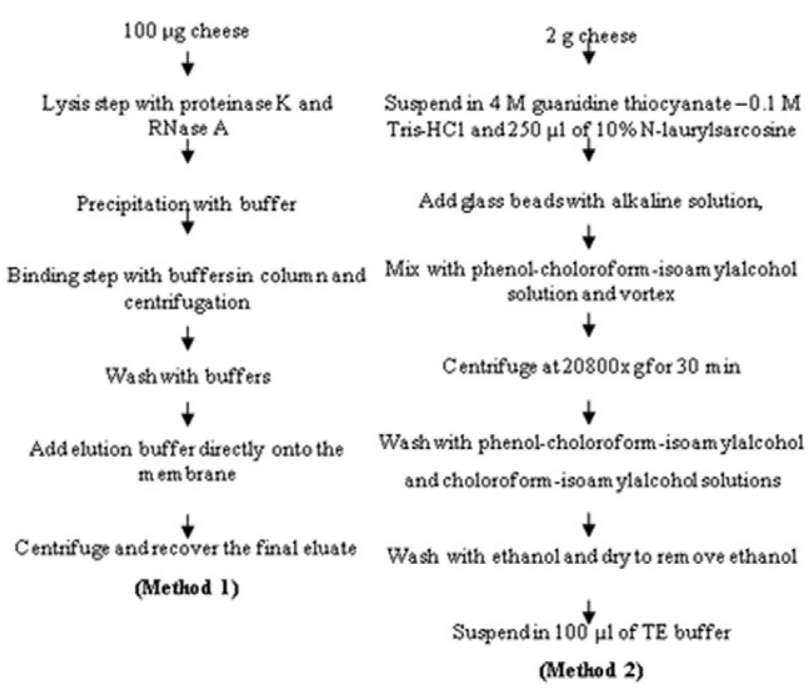

from a local supermarket in İzmir and they were originally free of S. aureus. Four different bacterial DNA extraction procedures were carried out directly from these samples.

For quantification of $S$. aureus in naturally contaminated cheese samples, cheese samples $(n=7)$ were collected from different bazaars in İzmir district (Turkey) and analyzed immediately using traditional culture method and incubated at $37{ }^{\circ} \mathrm{C}$ for $24-48 \mathrm{~h}$. The traditional plate count method included homogenization of $25 \mathrm{~g}$ sample in $225 \mathrm{~mL}$ buffered peptone water and plating $0.1 \mathrm{~mL}$ aliquots in Baird Parker agar supplemented with egg yolk tellurite emulsion and incubation at $37{ }^{\circ} \mathrm{C}$ for $24-48 \mathrm{~h}$.

\subsection{Bacterial DNA isolation from cheese samples}

For quantitative detection of $S$. aureus, the bacterial DNA was extracted from artificially contaminated cheese with four different methods (Fig. 1). The main steps were followed according to the previously given procedures, but significant modifications were applied to improve the sensitivity of detection. The $C_{t}$ values obtained using these isolation methods were analyzed by using Fisher's test and analysis of variance (ANOVA) using MINITAB $®$ release 14 (Minitab Inc., State College, USA).

\subsubsection{Bacterial DNA extraction using the food DNA extraction kit (Method 1)}

A commercial kit based on silica-gel membrane technology for rapid and efficient purification of DNA without organic extraction and ethanol precipitation (Intron Biotechnology, Inc., Korea) was applied according to the manufacturers' instructions. The steps in this procedure included lysis with lysis buffer, proteinase $\mathrm{K}$ and RNase A, precipitation, binding, and washing steps with buffer solutions. After selective binding of DNA to the column, the final eluate was recovered with elution buffer.

\subsubsection{Bacterial DNA extraction using beads (Method 2)}

The bacterial DNA extraction from artificially contaminated cheese samples was carried out using the procedure assessed by Bonaiti et al. (2006) with slight modifications. Briefly, $2 \mathrm{~g}$ of cheese sample was
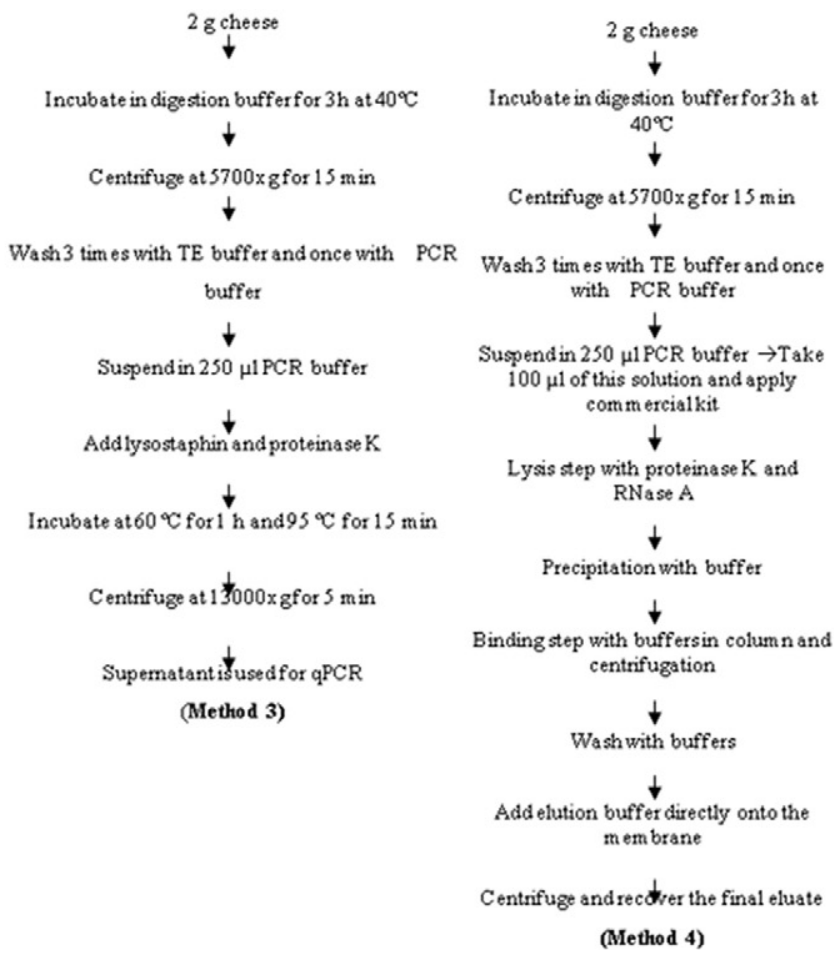

Fig. 1. Methods used for DNA extraction from cheese samples. 
suspended in $4 \mathrm{~mL}$ of $4 \mathrm{M}$ guanidine thiocyanate-0.1 M Tris- $\mathrm{HCl}$ ( $\mathrm{pH} 7.5$ ) and $250 \mu \mathrm{L}$ of $10 \% \mathrm{~N}$-lauroylsarcosine. For the DNA isolation, $2 \mathrm{~mL}$ Eppendorf tubes were filled with $200 \mathrm{mg}$ of glass beads $(0.25-$ $0.50 \mathrm{~mm}$ diameter) and with the alkaline solution which consists of $50 \mu \mathrm{L}$ mixture of $20 \%$ sodium dodecyl sulfate (SDS) solution, $300 \mu \mathrm{L}$ of $0.1 \mathrm{M}$ phosphate buffer $\mathrm{pH} 8.0,300 \mu \mathrm{L}$ of $50 \mathrm{mM}$ sodium acetate and $10 \mathrm{mM}$ EDTA (pH 5.5). Then $400 \mu \mathrm{L}$ phenol-chloroform-isoamyl alcohol $(25: 24: 1)$ at $\mathrm{pH} 8.0$ was added. The tube was vortexed for $30 \mathrm{~s}$. After cooling the samples on ice for $1 \mathrm{~min}$, vortexing was repeated. After centrifugation at $20,800 \times g$ for $30 \mathrm{~min}$, the upper aqueous phase was decanted. Afterwards, two washing steps were performed, firstly with phenol-chloroform-isoamyl alcohol (25:24:1; pH 8.0) and then with chloroform-isoamyl alcohol (24:1). The bacterial DNA was precipitated by addition of 2 volumes of cold absolute ethanol to the aqueous phase. Following incubation at $-20{ }^{\circ} \mathrm{C}$ for $2 \mathrm{~h}$, the DNA was centrifuged at $20,800 \times \mathrm{g}$ for $15 \mathrm{~min}$. The pellet was washed twice with $80 \%$ ethanol, dried and resuspended in $100 \mu \mathrm{L}$ of Tris-EDTA, and $5 \mu \mathrm{L}$ of the DNA solution was used for qPCR analysis.

\subsubsection{Bacterial DNA extraction using trypsin (Method 3)}

The procedure of Hein et al. (2001) with slight modifications was applied. In summary, $2 \mathrm{~g}$ of cheese sample was mixed with $45 \mathrm{~mL}$ of digestion buffer containing $1 \mathrm{mg}$ trypsin per $\mathrm{mL}$ and subsequently homogenized in a stomacher for $1 \mathrm{~min}$, and incubated at $40{ }^{\circ} \mathrm{C}$ for $3 \mathrm{~h}$. After centrifugation at $5700 \times g$ for $15 \mathrm{~min}$ at $4{ }^{\circ} \mathrm{C}$, the fat layer and aqueous phases were discarded and the pellet was washed three times with TE buffer (10 mM Tris-HCl, $1 \mathrm{mM}$ EDTA at $\mathrm{pH} 7.5$ ) and once with the PCR buffer ( $50 \mathrm{mM} \mathrm{KCl}, 1.5 \mathrm{mM} \mathrm{MgCl}_{2}, 10 \mathrm{mM}$ Tris-HCl at pH 8.4). Finally, the pellet was resolved in $250 \mu \mathrm{L}$ of PCR buffer. Lysostaphin and proteinase $\mathrm{K}$ solutions were added to this solution and incubated for 1 $\mathrm{h}$ and $15 \mathrm{~min}$ at 60 and $95{ }^{\circ} \mathrm{C}$, respectively. After centrifugation at $13,000 \times g$ for $5 \mathrm{~min}, 5 \mu \mathrm{L}$ of supernatant was subjected to qPCR analysis.

\subsubsection{Bacterial DNA extraction using trypsin and followed by food DNA kit method (Method 4)}

In this method, the food DNA extraction kit procedure described in Method 1 was combined with modified Hein et al. (2001) procedure described in Method 3. The process steps described in Method 3 were followed until the pellet was resolved in $250 \mu \mathrm{L}$ of PCR buffer and continued with the procedure described in Method 1. To the best of our knowledge, this method was first performed in our study.

\subsection{TaqMan and LNA probe-based qPCR assay}

The primers were used in the study targeting the nuc gene of S. aureus. The size of the amplified product was expected to be $124 \mathrm{bp}$ in length. TaqMan probe was labeled with 6-carboxy-fluorescein (FAM) and with 6-carboxy-tetramethyl-rhodamine (TAMRA) at $5^{\prime}$ and $3^{\prime}$ ends, respectively. The primers and the probe were used as reported by Alarcón et al. (2006). The LNA probe (AtCACaAACaGAtAACGGCG) was designed using lna-tm.com program in exiqon website (http:// www.exiqon.com/ls/homeoflna/Oligo-tools/tm-prediction-tool.htm) consisting of 4 LNA monomers shown with the lowercase letters. The qPCR amplifications were carried out in a total volume of $20 \mu \mathrm{L}$. This mixture composed of $10 \times$ probe master, $500 \mathrm{nM}$ of each primer, $200 \mathrm{nM}$ probe and $5 \mu \mathrm{L}$ of template DNA. The thermal cycling program started at $95{ }^{\circ} \mathrm{C}$ for $10 \mathrm{~min}$ of incubation. 50 cycles of amplification included $95{ }^{\circ} \mathrm{C}$ for $15 \mathrm{~s}$ denaturation step, annealing at $60{ }^{\circ} \mathrm{C}$ for TaqMan and $57^{\circ} \mathrm{C}$ for LNA probes. The reaction ended with an extension step at $72{ }^{\circ} \mathrm{C}$ for $1 \mathrm{~s}$. The data analyses were carried out using LightCycler ${ }^{\circledR}$ 480 Instrument software version 1.5 (Roche Diagnostics).

The standard curves for each probe were constructed by tenfold serial dilutions of $S$. aureus strain cells in buffered peptone water. The main stock solution was prepared by adjusting the turbidity of the solution to 0.5 McFarland standard. DNA isolation of each calibrated solution was performed and used to obtain the corresponding standard curve.

\section{Results and discussion}

\subsection{Sensitivity assays on S. aureus pure culture}

For determination of the detection limit and quantification range, the standard curves were constructed with bacterial DNA isolated from S. aureus pure culture with TaqMan and LNA probes. The standard curves were constructed with $C_{t}$ values obtained with TaqMan (Fig. 2a) and LNA (Fig. 2c) probe-based qPCR assays corresponding to tenfold dilutions of DNA isolated from S. aureus RSKK 1009 in a range between $10^{0}$ and $10^{7} \log _{10} \mathrm{CFU} / \mathrm{mL}$. Efficiency (E) of the qPCR assay was calculated as 0.81 and 0.76 for TaqMan and LNA probes, respectively. LNA probe was slightly less efficient for quantification of S. aureus cells.

\subsection{Sensitivity assays on artificially contaminated cheeses}

\subsubsection{The effect of bacterial DNA extraction method}

The purity and quantity of DNA isolates are significant for efficient PCR analysis. The DNA purity value which is calculated by taking the ratio of absorbance at $A_{260}$ to $A_{280}$ between 1.7 and 2.0 could be used for quantification purposes. Nanodrop results of DNA samples extracted by this method directly from cheese samples contaminated with S. aureus at the highest level $\left(10^{7} \mathrm{CFU} / \mathrm{mL}\right)$ were given in Table 1 . Nanodrop results of the methods revealed that DNA yield was not correlated with the purity of the extracted DNA. In Method 4, the amount and the purity of the DNA were good enough to provide accurate quantification.

In an attempt to find the most sensitive qPCR method, these four procedures were compared according to their $C_{t}$ values. The average $C_{t}$ values were $27.8 \pm 0.58,34.2 \pm 1.20$, and $25.5 \pm 0.24$ for Methods 1,2 , and 4 , respectively. Method 3 did not show amplification and this could be due to isolation of non-specific DNA target or PCR inhibitors. The difference between the $C_{t}$ values of these methods was statistically significant $(P<0.05)$. The lowest $C_{t}$ value corresponding to the highest sensitivity was obtained with Method 4 . This could be described by the long incubation period of $3 \mathrm{~h}$ used for digestion and selective binding of DNA to silica gel membrane following binding and precipitation steps. Thus different $C_{t}$ values of the target bacterial gene could be related to differences in bacterial DNA extraction efficiency.

In direct detection of pathogens applied to food samples, the efficiency of extraction can be reduced by inhibitory substances such as fats, proteins and high concentration of $\mathrm{Ca}^{2+}$ (Cremonesi et al., 2006). The DNA extraction procedures from food samples play an important role in detecting pathogens using qPCR.

These results also showed that it was important to prepare standard curves for the cells in actual food samples since the curve could change with the actual samples. The levels of standard deviation were low enough to allow accurate quantification. The reason for finding a lower $\mathrm{R}^{2}$ value of the curve obtained from the direct DNA isolation method from the curve of the qPCR system obtained from serial dilutions of reference strain could be the presence of high quantity of proteins and fats present in the cheese that might adsorb or prevent detergents, chaotropic agent, chelating agents or beads from accessing to the cells (Bonaiti et al., 2006).

It was found to detect the bacterial level of $13.2 \mathrm{CFU} / \mathrm{g}$ which was the lowest amount that amplification was observed. Poli et al. (2007) reported that detection of $S$. aureus was lower than $10^{3} \mathrm{CFU} / \mathrm{g}$ in cheese samples by nuсA targeted real-time PCR assay. Alarcón et al. (2006) reported that $4.9 \times 10^{3} \mathrm{CFU} / \mathrm{g}$ had to be present to give positive reaction with TaqMan probe in food samples. In another study, real time qPCR was applied to quantify $S$. aureus cells in artificially contaminated cheeses of different types. It was demonstrated that $1.5 \times 10^{2}$ to $6.4 \times 10^{3}$ copies of the nuc gene $/ 2 \mathrm{~g}$ cheese could be detected based on the cheese matrix 

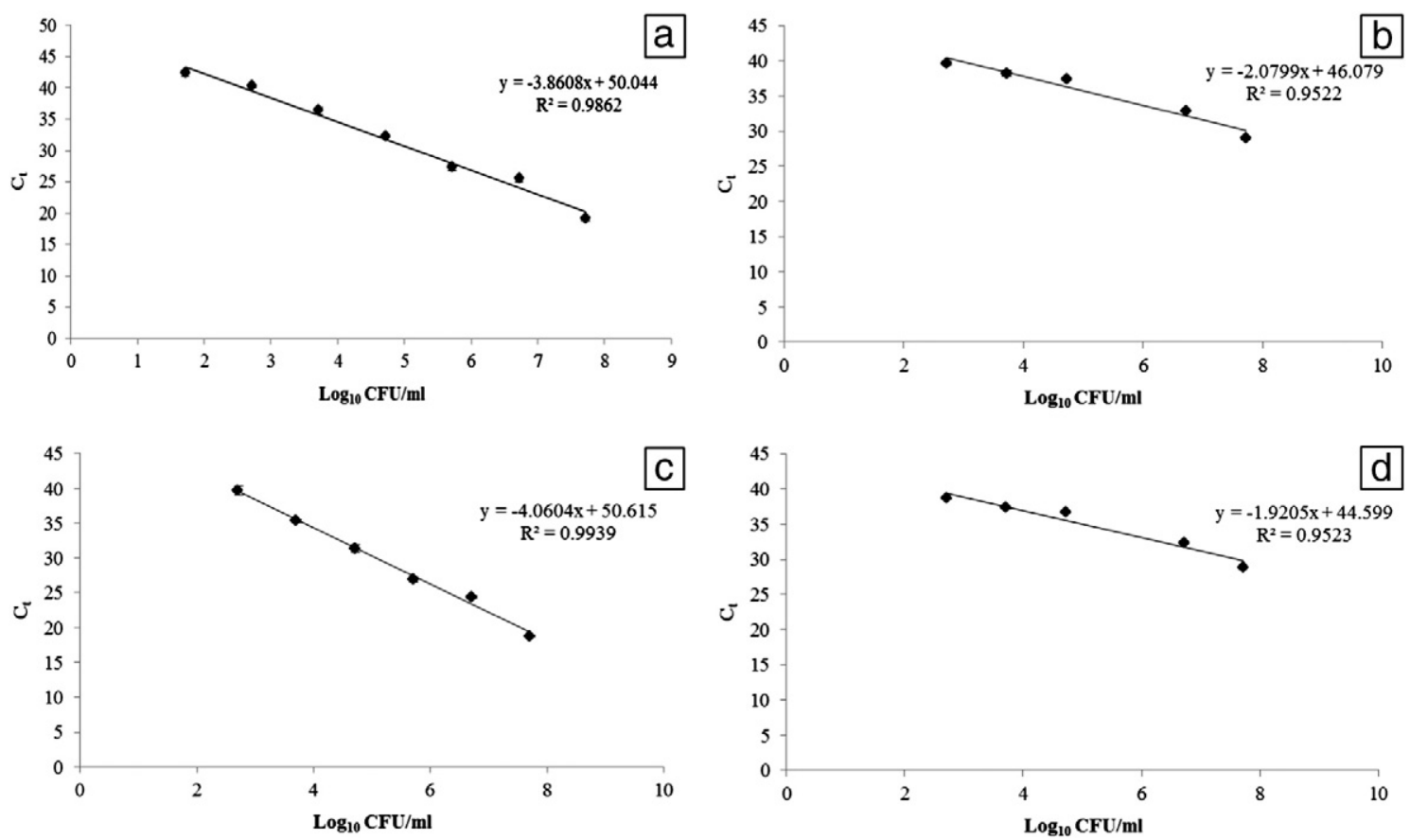

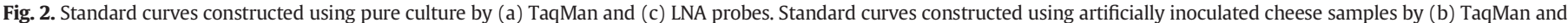
(d) LNA probes.

(Hein et al., 2001). Detection sensitivity improved approximately one log order by using the improved DNA extraction method in this study.

\subsubsection{The effect of the probe type (TaqMan vs LNA probes)}

The performances of TaqMan and LNA probes were evaluated with the genomic DNA isolated from the cheese samples artificially contaminated with S. aureus in the qPCR methodology. DNA extraction was performed from these cheese samples by the improved DNA isolation method. The qPCR experiments were carried out by using the isolated genomic DNA. Standard curves were constructed by using genomic DNA solutions for both of TaqMan and LNA probes (Fig. $2 b$ and d). The bacterial numbers were shown in the form of $\log _{10} \mathrm{CFU} / \mathrm{mL}$. The $\mathrm{E}$ and $\mathrm{R}^{2}$ values were calculated as 2.02 and 0.9522 for TaqMan probe. The $\mathrm{E}$ of LNA probe was 2.32 and $\mathrm{R}^{2}$ of the standard curve was 0.9523 . Lower efficiency values were obtained in these studies.

Table 1

Nanodrop measurements of DNA isolates obtained with different DNA extraction methods.

\begin{tabular}{lrc}
\hline Sample no & DNA amount ng/ $\mu \mathrm{L}$ & $\mathrm{A}_{260} / \mathrm{A}_{280}$ \\
\hline Method 1 & 17.12 & 3.37 \\
1 & 12.11 & 3.11 \\
2 & 10.01 & 1.81 \\
3 & & \\
Method 2 & 15.11 & 1.18 \\
1 & 54.23 & 0.93 \\
2 & 389.17 & 1.24 \\
3 & & \\
Method 3 & 30.76 & 1.26 \\
1 & 163.31 & 1.31 \\
2 & 163.57 & 0.91 \\
3 & & \\
Method 4 & 37.30 & 1.97 \\
1 & 26.17 & 1.92 \\
2 & 20.43 & 2.06 \\
3
\end{tabular}

In contrast to our results, Josefsen et al. (2009) stated that the sensitivity of LNA probes was higher than that of TaqMan probes for the detection of thermotolerant Campylobacter. In another study, LNA probes also had higher sensitivities than TaqMan probes in one of the studies in which combinations of different dyes combined with TaqMan probes were tested and compared to LNA probes for the detection of Salmonella in fishmeal, pig feces and chicken neck skin (Reynisson et al., 2006). However, obtaining lower sensitivities both in the pure culture and the artificially contaminated cheese samples with the LNA probe in our study could be related to the lack of strict rules for LNA probe design for S. aureus. Accordingly, the TaqMan probe was selected for use in further quantification purposes in white cheese samples.

\subsection{Quantification of S. aureus in naturally contaminated cheeses by $q P C R$}

In this part of the study, standard curves generated by using artificially inoculated cheese samples were used to calculate the bacterial numbers in naturally contaminated cheese samples. The improved DNA extraction method (Method 4) was used with TaqMan probebased qPCR assay in detection of $S$. aureus in naturally contaminated cheese samples. Plate counts and qPCR enumeration in naturally contaminated cheese samples are given in Table 2. The qPCR counts were found to be higher than plate counts indicating that the number of dead cells was higher than live cells. In Turkey, cheeses sold in the bazaars are assumed to be heat treated. The presence of the live bacteria

Table 2

Plate counts and qPCR enumeration in naturally contaminated cheese samples.

\begin{tabular}{llll}
\hline Samples & $\begin{array}{l}\text { Plating } \\
\log \text { CFU/g }\end{array}$ & $\begin{array}{l}\mathrm{C}_{\mathrm{t}} \text { TaqMan } \\
\text { (mean) }\end{array}$ & $\begin{array}{l}\text { TaqMan } \\
\log \text { copy number/g }\end{array}$ \\
\hline 1 & 3.18 & 33.60 & 5.70 \\
2 & 4.93 & 35.23 & 4.92 \\
3 & 3.43 & 32.31 & 6.32 \\
4 & 1.98 & 34.00 & 5.51 \\
5 & 3.01 & 37.12 & 4.01 \\
6 & 3.89 & 37.42 & 3.86 \\
7 & 2.18 & 37.03 & 4.05 \\
\hline
\end{tabular}


indicates either cross-contamination or inefficient heat treatment during production.

The importance of the study is the development of a qPCR method for quantification of $S$. aureus without traditional culturing methods. The highest microbial counts of $S$. aureus in cheese samples are determined as $10^{5} \mathrm{CFU} / \mathrm{g}$ for production of enterotoxins by the official regulations (Alomar et al., 2008). Although pasteurization of milk, fermentation and ripening steps retard $S$. aureus growth, it is important to detect and quantify this pathogenic bacterium in cheese (Akineden et al., 2008). By this qPCR method species specific detection was performed under the described conditions. The difference between qPCR and plate count results revealed that most of the bacteria could not be counted by classical plate counting method. The reason for this could be related to a few numbers of clusters formed by the bacteria causing less number of plate count results (Hein et al., 2001). Another reason for this difference was described by detection of dead and viable cells together (Mäntynen et al., 1997). The dead cells could not be detected by the plate count method. The coefficient of correlation between the qPCR and plate count methods was high enough (0.9815) for the artificially contaminated cheese samples. Therefore, it is possible to calculate the plate counts by using the qPCR results.

The target gene, the thermostable nuclease enzyme that is encoded by the nuc gene, is expressed under similar conditions and shows comparable stability properties with staphylococcal enterotoxins (Brakstad et al., 1992; Meyrand et al., 1999; Tang et al., 2008). Therefore, the laborious and expensive methods used for detection of enterotoxins in routine analysis of food products can be replaced by the detection of the nuc gene (Szabo, 2001). The microbiological criteria for the presence of coagulase positive Staphylococcus species established by Food and Drug Administration (FDA (Food and Drug Administration) Circular, 2013) and Turkish Food Codex (Turkish Food Codex, 2011) were in the range between $10^{2}$ and $10^{3} \mathrm{CFU} / \mathrm{g}$ which were the acceptable limit and potential health hazard limit for the cheese samples, respectively. In this study, the number of coagulase positive Staphylococcus bacterial counts was higher than the established limits in 5 of the 7 cheese samples investigated with plating method. According to qPCR analyses, all 7 cheese samples were detected to contain higher than $10^{3} \mathrm{CFU} / \mathrm{g}$ $S$. aureus. This qPCR result indicated the number of live and dead cells together. Based on the presumptive bacterial counts obtained with plating method and the $S$. aureus numbers quantified with qPCR method, it was concluded that most of the $S$. aureus cells were dead during the pasteurization process of cheese manufacturing. However, S. aureus heat stable toxins were not eliminated during pasteurization process. S. aureus bacterial counts higher than $10^{5} \mathrm{CFU} / \mathrm{g}$ were considered to carry health risk by the formation of staphylococcal enterotoxins (Alomar et al., 2008). Therefore, from the point of determining the risk of toxin formation due to high number of $S$. aureus cells, the qPCR analyses could be used as a guide for quantification of S. aureus.

\section{Conclusions}

The results reported herein show that a new DNA isolation method based on trypsin treatment followed by the application of a commercial kit in combination with quantitative TaqMan probe-based qPCR was found to be the most suitable for sensitive quantitative detection of $S$. aureus in white cheese samples. The efficiency of the LNA probebased qPCR assay was found to be lower than the TaqMan probebased assay in pure culture of $S$. aureus and artificially contaminated cheese sample studies as opposed to the previous studies. The standard curves were constructed directly using artificially contaminated cheese samples and were used to estimate $S$. aureus cell counts in naturally contaminated cheese samples. In naturally contaminated cheese samples, the number of $S$. aureus counts was higher when obtained with qPCR analyses which indicated the total number of live and dead cells from the presence of staphylococcal enterotoxins in live and dead cells.

\section{Acknowledgment}

This research was supported by the Research Funds of Izmir Institute of Technology (project no. 2010-IYTE-05). We acknowledge "Izmir Institute of Technology, Biotechnology and Bioengineering Research and Application Center" for their assistance during qPCR analyses.

\section{References}

Abdunaser, D., Almabrouk, F., Ashraf, W., Yves, M., Olivier, C., Moez, S., 2009. Combination of most-probable-number method with light cycler real-time PCR assay (MPN-realtime PCR) for rapid quantification of Salmonella in artificially and naturally contaminated bovine fecal samples at slaughter house. Iraqi J. Vet. Sci. 23, 231-243.

Akineden, Ö., Hassan, A.A., Schneider, E., Usleber, E., 2008. Enterotoxigenic properties of Staphylococcus aureus isolated from goats' milk cheese. Int. J. Food Microbiol. 124 211-216.

Alaboudi, A.R., Jaradat, Z.W., Shatnawi, M.M., 2012. Biotypes and enterotoxigenicity of Staphylococci isolated from camel's meat in Jordan. Brit. Microbiol. Res. J. 2, 23-35.

Alarcón, B., Vicedo, B., Aznar, R., 2006. PCR-based procedures for detection and quantification of Staphylococcus aureus and their application in food. The Society for Applied Microbiology, J. Appl. Microbiol., 100, pp. 352-364.

Alomar, J., Lebert, A., Montel, M.C., 2008. Effect of temperature and pH on growth of Staphylococcus aureus in co-culture with Lactococcus garvieae. Curr. Microbiol. 56, 408-412.

Bonaiti, C., Parayre, S., Irlinger, F., 2006. Novel extraction strategy of ribosomal RNA and genomic DNA from cheese for PCR-based investigations. Int. J. Food Microbiol. 107, 171-179.

Brakstad, O.G., Aasbakk, K., Maeland, J.A., 1992. Detection of Staphylococcus aureus by polymerase chain reaction amplification of the nuc gene. J. Clin. Microbiol. 30 1654-1660.

Cremonesi, P., Castiglioni, B., Malferrari, G., Biunno, I., Vimercati, C., Moroni, P., Morandi, S., Luzzana, M., 2006. Technical note: improved method for rapid DNA extraction of mastitis pathogens directly from milk. J. Dairy Sci. 89, 163-169.

Cremonesi, P., Perez, G., Pisoni, G., Moroni, P., Morandi, S., Luzzana, M., Brasca, M. Castiglioni, B., 2007. Detection of enterotoxigenic Staphylococcus aureus isolates in raw milk cheese. The Society for Applied Microbiology, Lett. Appl. Microbiol., 45, pp. 586-591.

D'Urso, O.F., Poltronieri, P., Marsigliante, S., Storelli, C., Hernández, M., Rodríguez-Lázaro, D., 2009. A filtration-based real-time PCR method for the quantitative detection of viable Salmonella enterica and Listeria monocytogenes in food samples. Food Microbiol. 26, 311-316.

Ercolini, D., Blaiotta, G., Fusco, V., Coppola, S., 2004. PCR-based detection of enterotoxigenic Staphylococcus aureus in the early stages of raw milk cheese making. J. Appl. Microbiol. 96, 1090-1096.

Ertas, N., Gonulalan, Z., Yildirim, Y., Kum, E., 2010. Detection of Staphylococcus aureus enterotoxins in sheep cheese and dairy desserts by multiplex PCR technique. Int. J. Food Microbiol. 142, 74-77.

Federico, B., Matarante, A., Caputo, L., Morea, M., 2005. Development of a cultureindependent polymerase chain reaction-based assay for the detection of lactobacilli in stretched cheese. J. Rapid Methods Autom. Microbiol. 13, 177-192.

FDA (Food and Drug Administration) Circular, 2013. Revised guidelines for the assessment of microbiological quality of processed foods.

Fusco, V., Quero, G.M., Morea, M., Blaiotta, G., Visconti, A., 2011. Rapid and reliable identification of Staphylococcus aureus harbouring the enterotoxin gene cluster (egc) and quantitative detection in raw milk by real time PCR. Int. J. Food Microbiol. $144,528-537$.

Gachon, C., Mingam, A., Charrier, B., 2004. Real-time PCR: what relevance to plant studies? J. Exp. Bot. 55, 1445-1454.

Ginzinger, D.G., 2002. Gene quantification using real-time quantitative PCR: an emerging technology hits the mainstream. Exp. Hematol. 30, 503-512.

Hein, I., Lehner, A., Rieck, P., Klein, K., Brandl, E., Wagner, M., 2001. Comparison of different approaches to quantify Staphylococcus aureus cells by real-time quantitative PCR and application of this technique for examination of cheeses. Appl. Environ. Microbiol. 67, 3122-3126.

Hein, I., Jørgensen, H.J., Loncarevic, S., Wagner, M., 2005. Quantification of Staphylococcus aureus in unpasteurised bovine and caprine milk by real-time PCR. Res. Microbiol. $156,554-563$.

Hummerjohann, J., Naskova, J., Baumgartner, A., Graber, H.U., 2014. Enterotoxin-producing Staphylococcus aureus genotype B as a major contaminant in Swiss raw milk cheese. J. Dairy Sci. 97, 1305-1312.

Huong, B.T.M., Mahmud, Z.H., Neogi, S.B., Kassu, A., Nhien, N.V., Mohammad, A., Yamato M., Ota, F., Dao, N.T.L.H.T.A., Khan, N.C., 2010. Toxigenicity and genetic diversity of Staphylococcus aureus isolated from Vietnamese ready-to-eat foods. Food Control 21, 166-171.

Jepsen, J.S., Sørensen, M.D., Wengel, J., 2004. Locked nucleic acid: a potent nucleic acid analog in therapeutics and biotechnology. Oligonucleotides 14, 130-146.

Josefsen, M.H., Löfström, C., Sommer, H.M., Hoorfar, J., 2009. Diagnostic PCR: comparative sensitivity of four probe chemistries. Mol. Cell. Probes 23, 201-203.

Letertre, C., Perelle, S., Dilasser, F., Arar, K., Fach, P., 2003. Evaluation of the performance of LNA and MGB probes in 5'-nuclease PCR assays. Mol. Cell. Probes 17, 307-311.

Mäntynen, V., Niemelä, S., Kaijalainen, S., Pirhonen, T., Lindström, K., 1997. MPN-PCRquantification method for staphylococcal enterotoxin cl gene from fresh cheese. Int J. Food Microbiol. 36, 135-143. 
Martínez-Blanch, J.F., Sánchez, G., Garay, E., Aznar, R., 2009. Development of a real-time PCR assay for detection and quantification of enterotoxigenic members of Bacillus cereus group in food samples. Int. J. Food Microbiol. 135, 15-21.

Meyrand, A., Atrache, V., Bavai, C., Montet, M.P., Vernozy-Rozand, C., 1999. An automate method for the detection of staphylococcal heat stable deoxyribonuclease in dairy products. Lett. Appl. Microbiol. 29, 216-220.

Miranda, J.M., Mondragón, A., Vázqueza, B.I., Fentea, C.A., Cepedaa, A., Francoa, C.M. 2009. Microbiological quality and antimicrobial resistance of Escherichia coli and Staphylococcus aureus isolated from conventional and organic "Arzúa-Ulloa" cheese. Cyta-J. Food 7, 103-110.

Morandi, S., Brasca, M., Lodi, R., Cremonesi, P., Castiglioni, B., 2007. Detection of classica enterotoxins and identification of enterotoxin genes in Staphylococcus aureus from milk and dairy products. Vet. Microbiol. 124, 66-72.

Peles, F., Wagner, M., Varga, L., Hein, I., Rieck, P., Gutser, K., Keresztúri, P., Kardos, G., Turcsányi, I., Béri, B., Szabó, A., 2007. Characterization of Staphylococcus aureus strains isolated from bovine milk in Hungary. Int. J. Food Microbiol. 118, 186-193.

Pennacchia, C., Ercolini, D., Villani, F., 2009. Development of a real-time PCR assay for the specific detection of Brochothrix thermosphacta in fresh and spoiled raw meat. Int. J. Food Microbiol. 134, 230-236.

Poli, A., Guglielmini, E., Sembeni, S., Spiazzi, M., Dellaglio, F., Rossi, F., Torriani, S., 2007 Detection of Staphylococcus aureus and enterotoxin genotype diversity in Monte
Veronese, a protected designation of origin Italian cheese. The Society for Applied Microbiology. Lett. Appl. Microbiol. 45, 529-534.

Reynisson, E., Josefsen, M.H., Krause, M., Hoorfar, J., 2006. Evaluation of probe chemistries and platforms to improve the detection limit of real-time PCR. J. Microbiol. Meth. 66, 206-216.

Schelin, J., Wallin-Carlquist, N., Cohn, M.T., Lindqvist, R., Barker, G.C., Rådström, P., 2011. The formation of Staphylococcus aureus enterotoxin in food environments and advances in risk assessment. Virulence 2, 580-592.

Sudagidan, M., Çavuşoğlu, C., Bacakoğlu, F., 2008. Investigation of the virulence genes in methicillin-resistant Staphylococcus aureus strains isolated from biomaterial surfaces. Mikrobiyol. Bul. 42, 29-39.

Szabo, R.A., 2001. Determination of Staphylococcus aureus thermostable nuclease in food. Microbiology Food Health Protection Branch (Canadian Food Inspection Agency) (Available from: http://www.hc-sc.gc.ca/food-aliment).

Tang, J., Zhou, R. Shi, X. Kang M. Wang. H., Chen, H., 2008. Two thermostable nucleases coexisted in Staphylococcus aureus: evidence from mutagenesis and in vitro expression. FEMS Microbiol. Lett. 284, 176-183.

Temelli, S., Anar, S., Sen, C., Akyuva, P., 2006. Determination of microbiological contamination sources during Turkish white cheese production. Food Control 17, $856-861$

Turkish Food Codex, 2011. Microbiological criteria. Annex-1, food safety criteria. 